\title{
Effect of urban built form and density on building energy performance in temperate climates
}

\section{Abstract}

Urban built form and density are crucial parameters for the optimization of building energy performance. However, a cohesive framework which correlates building energy with urban built form and density is lacking, with no unified agreement on the concept of urban density. This study establishes the subtle interrelationships between urban built forms, density and building energy performance using two density indicators, specifically, site coverage and plot ratio. This paper initially considers geometrical variables of four customary urban built forms to investigate their relationship with the density indicators. Energy analyses are performed on the geometrical models representing residential buildings using the City of London as an example of a temperate climate. Annual building energy demands of pavilion, terrace, court and tunnel-court forms are calculated. The findings are used to produce a heat map of energy intensity on the Form Signature graphs. Results show that high-rise buildings with greater plan depths achieve higher energy efficiency. Moreover, it is shown that greater cut-off angles correspond to higher energy demands under temperate climatic conditions. An energy indicator, termed Energy Equity is introduced which represents the ratio between $\mathrm{PV}$ energy generation installed on roofs with respect to the total energy demand of the building. Further analyses show that by considering energy demand and PV energy generation simultaneously, low-rise buildings with greater plan depths provide improved energy performance. A comparative analysis of the energy performance of different built forms with similar geometric parameters demonstrates that the tunnelcourt and the pavilion built forms provide the best and worst energy performance, respectively. However, when constraining density whilst changing other geometric parameters, this converse is true. Finally, the study illustrates that the same density for the same built form can be achieved by different combinations of geometric parameters that certainly affects energy performance of buildings. Graphic display of the analysis results provide urban planning guidelines that represent the database of major findings of this study. It can be used by designers, planners and architects to identify the most energyefficient built form and density for promoting more sustainable cities.

\section{Keywords}

urban built form, urban density, building energy demand, PV energy generation 


\section{Introduction}

Cities are the main consumers of energy accounting for $78 \%$ of the world's total usage and contributing to more than $60 \%$ of greenhouse gas emissions [1], and is expected to rise in the near future due to rapid urbanization [2]. Total city energy consumption is largely dependent on energy mix, climate and urban form $[3,4]$, which has a significant correlation with the energy demand of buildings [5]. Urban form has a variety of attributes such as density [6], compactness, diversity, green areas, connectivity, orientation, shading and passivity $[7,8]$ that affect energy consumption. To identify the relationship between energy consumption and urban form, the most widely used parameter is density $[4,9,10]$.

It has been reported that a compact built form with higher urban density results in less energy usage $[4,6,11]$ compared to urban sprawl $[12,13]$. However, there is emerging evidence challenging the compact city concept by indicating that a dispersed urban form may provide improved energy efficiency $[14,15]$. This is due to urban areas increasingly generating their own energy from renewable sources [16] such as roof-mounted PVs and ground source heat pumps, requiring a large area that cannot be achieved by compact buildings $[17,18]$.

Whilst there has been considerable research into the impact of urban form on building energy consumption and the renewable energy potential of cities, there remain two distinct gaps in previously reported research:

1. Urban density has been defined using a variety of indicators such as site coverage [19], plot ratio [20], volume-area ratio [21], building density [22], open space ratio [23], BPRU index/compactness index [24], surface to volume ratio [25], urban entropy [15], form factor [26] and habitable rooms per hectare [27]. This becomes challenging when attempting to compare and contrast the results of different studies [10]. Moreover, a single indicator cannot truly determine the definition of urban density in a comprehensive way [28].

2. Whilst several studies link energy generation to energy demand their analyses are either restricted to 'building' scale [29,30], or when considering an 'urban' scale they do not focus on the impact of urban form and density on building energy performance [31, 32]. There are also several studies that focusses on the impact of urban form (i.e. density) on building energy consumption $[33,34]$ and renewable energy generation $[14,16]$ separately or even jointly $[35$, 36]. However, they did not consider the effect of 'urban built form' and its influential geometrical 
variables along with density (including more than one indicator with intercorrelation) in their analysis. Therefore, there is a lack of a structure in the literature that is able to connect all the mentioned parameters with building energy and address their simultaneous intercorrelations.

In this study, the two most popular density indicators reported in literature viz. site coverage and plot ratio, are adopted to define urban density as they are directly obtained from the geometry of the built environment. Berghauser Pont and Haupt [37] employ them to conceive the Spacemate chart; a comprehensive indicator of density that can include energy performance. It does not, however, consider the contribution of urban built form. The impact of urban built form is crucial to microclimatic conditions [38] which impacts building energy demand [5]. Ahmadian et al. [28] used the two aforementioned indicators and added the impact of urban built form to them. They produced a suite of graphs called the Form Signature illustrating the correlation of density indicators with geometrical parameters of various built forms.

This paper aims to identify the impact of 'urban built form' and 'density' on building energy performance (i.e. building energy demand plus renewable energy generation). It adds a layer of energy performance to the Form Signature graphs by considering both building energy demand and solar energy generation from roof-mounted PVs. The study, therefore, addresses both identified gaps in current literature by proposing a novel urban energy planning tool for temperate climates, establishing correlations between building energy demand and PV energy generation with urban built form and density, using a set of indicators.

The study is underpinned by simulations of four built forms, namely, pavilion, court, terrace and tunnel-court forms for the climatic conditions of the City of London (UK). CitySim is chosen as the simulation platform for this study [39]. The selection criteria for the simulation tool are the capabilities of the software that matches the requirement of this study and the validity and its use for similar studies reported in the literature [40-42]. It has been previously validated using both monitored data and other energy simulation software. Specifically, Coccolo, Kämpf [43] validated CitySim against EnergyPlus software using two existing buildings. Also, Walter and Kämpf [44] validated CitySim against BESTEST

87 for calculating annual and peak heating/cooling energy demand of buildings. They also experimentally verified the tool using monitored data of the annual heating consumption of an EPFL campus building and achieved comparable results. Furthermore, the simulation model is validated in this study through a pilot investigation comprising of four terraced houses certified to the code for sustainable homes level 
915 , sited in Gainsborough (UK). CitySim considers the whole building block containing four houses as a 92 single volume, while other parameters and assumptions are the same as those for a previously reported 93 SAP prediction model [45]. The resulting annual heating demand obtained from CitySim is only $6 \%$ higher than the results obtained from SAP. The difference between the two models is considered to be due to CitySim including surrounding buildings (which is not the case in SAP simulations) that create a shadowing effect. It reduces the internal gains and consequently increases the heating demand [46, 47].

Residential buildings are considered throughout the study as these have the greatest contribution of building energy demand worldwide [48]. The result is an urban energy planning tool kit to address the interrelationship between urban form, urban density and building energy.

\section{Materials and methods}

The study adopts a mixed research methods approach [49] composed of empirical and quantitative techniques, as shown in Figure 1. Initially, geometric models of the four built forms are developed using

104 three influential geometric parameters. By changing these, the urban density of a site composed of 105 similar buildings is evaluated. This provides a variety of site plans for input to energy analyses.

106 Secondly, simulations are used to obtain building energy demand and solar energy generation potential

107 from roof-mounted PVs. The results are extended to the Form Signature graphs resulting in 'heat maps' 108 that is one of the major contributions of this study. Furthermore, the comparison of the energy 109 performance of the built forms are presented in bar charts and tables.

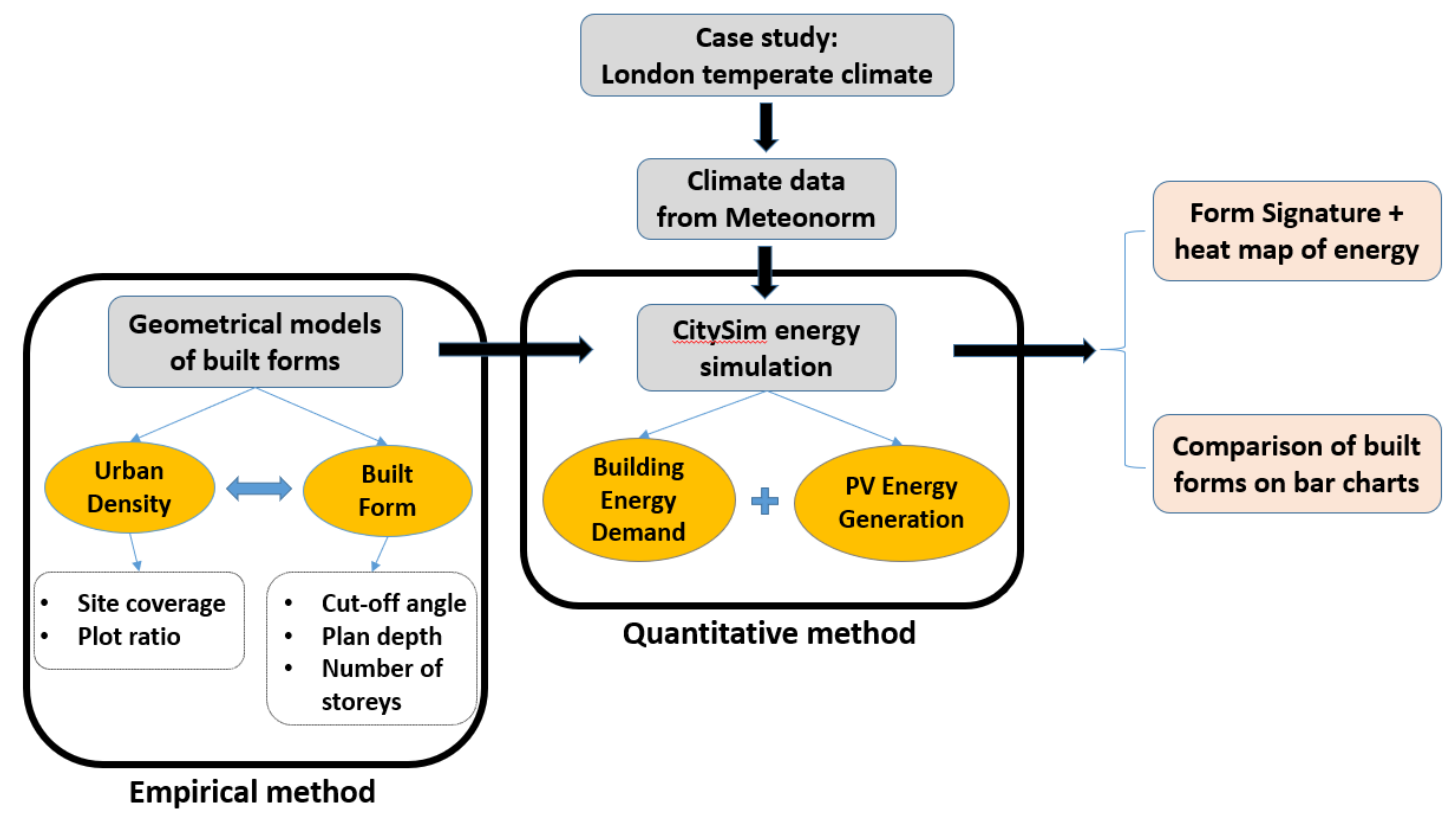


Four built forms namely pavilion, terrace, court and tunnel-court (Figure 2) are selected for this study to analyse and compare their densities and building energy performance. The forms are adopted due to their widespread application in research and practice $[24,50,51]$, and the availability of data relating to the two selected density indicators viz. site coverage and plot ratio in the Form Signature graphs [28].

118

119

120

121

122

123

124

125

126

127

128

129

130
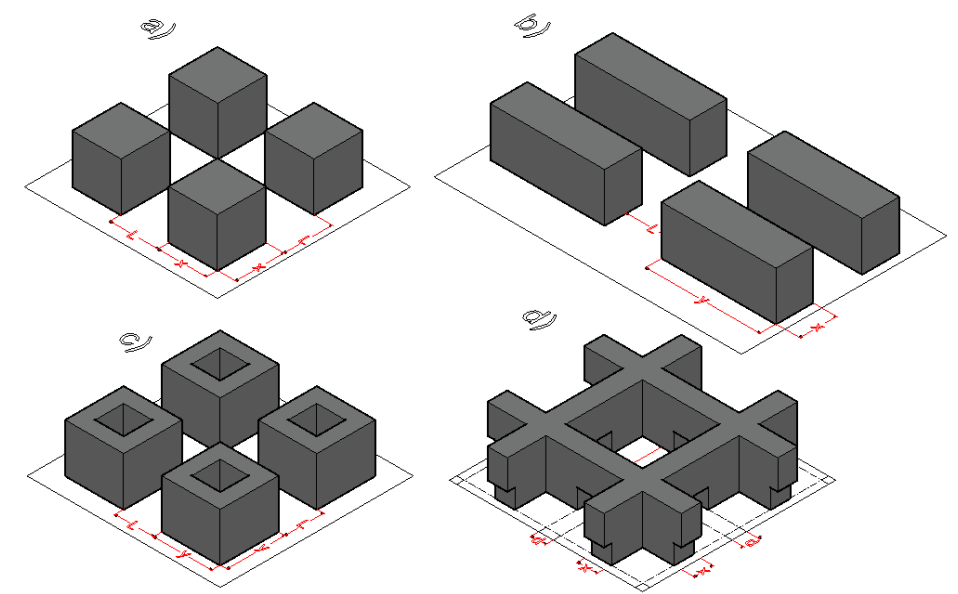

Figure 2: Geometrical models of the built forms a) pavilion b) terrace c) court d) tunnel-court built forms (adopted from [28])

Site coverage is defined as the ratio of 'total built area (covered by buildings) of the site' with respect to the 'total area of the site'. Plot ratio is defined as the ratio of 'total floor area of buildings' wrt. the 'total area of the site'. Plot ratio increases as the number of storeys increases, whilst site coverage does not change with the number of stories.

As shown in Figure 3, three geometrical parameters are selected for this analysis, namely, the cutoff angle $(\theta)$, the plan depth $(x)$ and the number of storeys $(n)$, where the cut-off angle changes the distance between buildings in the site plan $(L)$. By changing the geometry of each built form, the density of the site plan is changed, and due to the different shapes of the built forms the site coverage and plot ratio of each form subsequently changes. This has an impact on the energy performance of building which is investigated in this study through simulations.

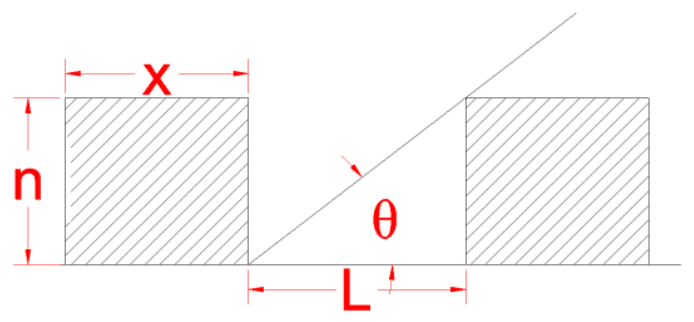




\subsection{Energy simulations}

134 Building energy consumption is affected by factors such as building characteristics (e.g. size, age, 135 materials, insulation, glazing ratio, window type, building energy system and built form) [52, 53], urban 136 planning (e.g. urban density is affected by variables such as the cut-off angle of the plan), occupant 137 density, user behaviour [54-56] and climate [57], with many being non-morphological factors [11]. By 138 using the simulation method, the mentioned parameters, except built form and density, can be kept 139 constant for all buildings.

140 CitySim allows consideration of the effects of the influential parameters in the urban energy 141 analysis such as shadowing between buildings as well as inter-reflection between external surfaces 142 through short/longwave radiations. Longwave radiation is considered by calculating the temperature of 143 the external surfaces that is affected by the geometry of street canyons [42]. High-density urban areas 144 maintain higher surface temperatures for longer periods of time by reducing the rate of longwave radiant 145 cooling at night [58]. This may increase the Urban Heat Island (UHI) effect that normally lowers heat 146 energy demand [59]. These are the parameters considered by CitySim that influence urban 147 microclimate and can strongly affect building energy demand [60]. Ideally, to investigate an urban 148 microclimate, computational fluid dynamic (CFD) analysis should be employed [61] alongside building 149 energy simulation studies [62]. This is a limitation of CitySim for this study that is not coupled with a 150 CFD method. CitySim benefits from a simplified thermal model providing a trade-off between input data 151 requirements, output precision and computational effort [44]. This simplified thermal model considers a single thermal zone per building that may affect the results specifically in taller buildings. However, this

153 limitation was tested in this study and the results showed around $7 \%$ difference with the case that considers multi-zone per building. However, this difference exists for all buildings with more than one storey that does not bring any difference in the whole trend of this comparative energy analysis and in the final comparison of different built forms.

157 Climatic data is obtained from Meteonorm software [63] and is integrated with CitySim to provide 15810 years average temperature data and 20 years average irradiation data. The data include air 159 temperature; surface temperature; beam radiation; horizontal diffuse radiation; wind speed; wind 160 direction; relative humidity; precipitation and cloud cover fraction on an hourly basis plus horizon data 161 containing information about natural obstacles around the location. Meteonorm database has been 
adopted for several similar studies $[15,26,41]$, however, CIM is able to calculates a high resolution profile of the meteorological variables [64] to provide more precise microclimate data. Using CIM mainly affects cooling loads of buildings, while in this study only heating/electricity demand of buildings are considered. Therefore, Meteonorm software is selected for this study that may cause some limitations compared to CIM.

\subsection{Case study, London (UK), $51.5^{\circ} \mathrm{N}, 0.13^{\circ} \mathrm{W}$}

\subsubsection{Building energy demand}

Following the generic models shown in Figure 2, site plans with an array of buildings of similar geometry are created as input to energy simulation studies (Figure 4).

a)

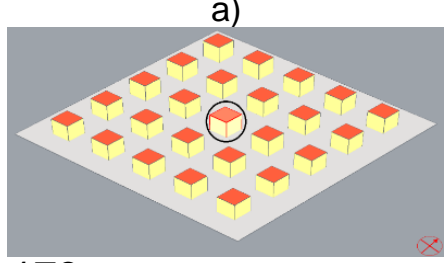

b)

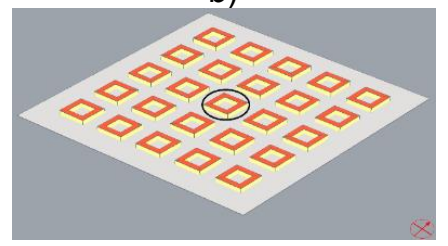

c)

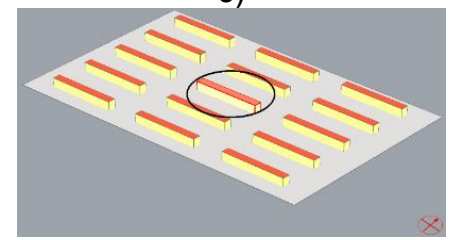

d)

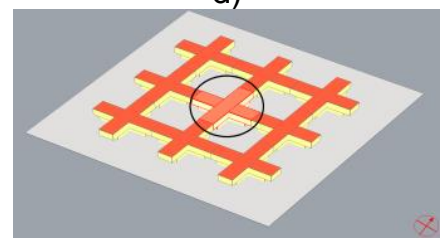

173

174

175

176

177

178

179

180

181

182

183

184

185

186

187

188

Figure 4: Model of the built district with a series of similar buildings with a) pavilion b) court c) terrace d) tunnel-court forms for energy simulation purpose. The target building is marked by a black circle.

For each built form in Figure 4, all buildings possess the same geometry, physical characteristics and occupancy profile. Circled blocks are target buildings while their surrounding buildings present neighbourhood conditions. Buildings are considered as black boxes that interact with each other and the outdoor environment while the conditions inside are considered the same.

Typical minimum and maximum internal setpoint temperatures are chosen to be $20^{\circ} \mathrm{C}$ and $24^{\circ} \mathrm{C}$, respectively [45]. The heating season begins in October and lasts until the end of May [45]. Due to the temperate climate of the UK and its mild summers, no cooling load is considered for residential buildings $[20,67]$. Infiltration rate of all buildings is chosen to be $0.5 \mathrm{ACH}[68]$. U-values of walls; roofs and floors are considered to be $0.18 ; 0.13$ and $0.13 \mathrm{~W} /\left(\mathrm{m}^{2} . K\right)$, respectively [69]. The $U$ and g-values for windows are $1.4 \mathrm{~W} /\left(\mathrm{m}^{2} . K\right)$ and 0.63 , respectively [45]. The percentage of glazing for residential buildings is a design parameter. Changing the glazing ratio can significantly impact building energy consumption [70]. A glazing ratio of $40 \%$ is adopted for this study to satisfy energy efficiency, provision of adequate daylight, natural ventilation and good views requirements [58]. Rode, Keim [20] have previously used the same value (40\%) for studying the correlation of urban morphology with heating energy in London. 
189 To make accurate comparisons between the different models, the density of occupants in all the models

190 was kept constant at 35 (m²/person). Following from Passive House Planning Package guidelines [71]

191 values of sensible heat, latent heat and radiant from occupants are considered to be 70 (W/person), 45

192 (W/person) and 60\%, respectively [72]. Lighting and appliances are considered to be the same for all

193 cases. To calculate the lighting energy demand, a mean value of 300 lux is considered for the whole

194 block. A high-efficiency model of LEDs (140 Im/ $\mathrm{M})$ is chosen [73], giving a mean power consumption

195 of $2.14 \mathrm{~W} / \mathrm{m}^{2}$. Typical consumptions of common home appliances are given in Table 1. To obtain the

196 consumption of the appliances in $W / m^{2}$ as required for CitySim, the average floor area of UK homes is

197 considered to be $85 \mathrm{~m}^{2}[74,75]$.

\begin{tabular}{|c|c|c|c|c|c|c|c|c|}
\hline Appliance & PC & TV & $\begin{array}{c}\text { Fridge- } \\
\text { freezer }\end{array}$ & $\begin{array}{c}\text { Washing } \\
\text { machine }\end{array}$ & $\begin{array}{c}\text { Hobs } \\
\text { (cooking) }\end{array}$ & $\begin{array}{c}\text { Microwave } \\
\text { oven }\end{array}$ & Kettle & Dishwasher \\
\hline Power (W) & 200 & 64 & 36 & 560 & 725 & 9 & 220 & 700 \\
\hline Source & {$[76]$} & \multicolumn{7}{|c|}{$[77]$} \\
\hline
\end{tabular}

198

Table 1: Appliances used for buildings

199

200

201

202

203

204

205

206

207

208

$$
E_{\text {equity }}=\frac{E_{\text {generation }}}{E_{\text {consumption }}}
$$

209

$E_{\text {equity }}>1$ indicates the building achieves an energy surplus, while $E_{\text {equity }}=1$ indicates energy self-

210 sufficiency.

\section{Results}

212 In the following, the correlation of building energy demand with urban built form and density is 213 considered, and the specific impact of cut-off angle on energy demand is evaluated. Then, heating 
214 energy demand is compared with electricity consumption. Finally, by considering PV energy generation,

215 the impact of urban built form and density on the total energy performance of the building is shown.

216

217

218

219 building plans with various dimensions and provides the opportunity to compare the results with those

220 previously reported in the literature [9]. To define the energy intensity of each point on a Form Signature

221 graph, simulations are conducted for a variety of site plans with different building geometries as follows:

222 - The number of storeys, $n=1,3,6,10,20$ and 30

223

224

225

226

227

\subsection{Building energy demand vs. urban built form and density}

The total annual heating and electricity energy demand of buildings per square metre of floor area is used in the following analysis. Units of $k W h / m 2 / y e a r$ facilitate an equitable assessment of different - Plan depths $(x)$ of $6 \mathrm{~m}$ to $60 \mathrm{~m}$ in $6 \mathrm{~m}$ intervals

- Cut-off angles $(\theta)$ of $25^{\circ}, 45^{\circ}$ and $65^{\circ}$ to examine the effect of distances between buildings Aggregated results are overlaid, point by point, on the Form Signature graphs (using MATLAB), as given in Figure 5, thereby showing the correlation between building heating/electricity energy demand with urban density for the different built forms and the three cut-off angles.
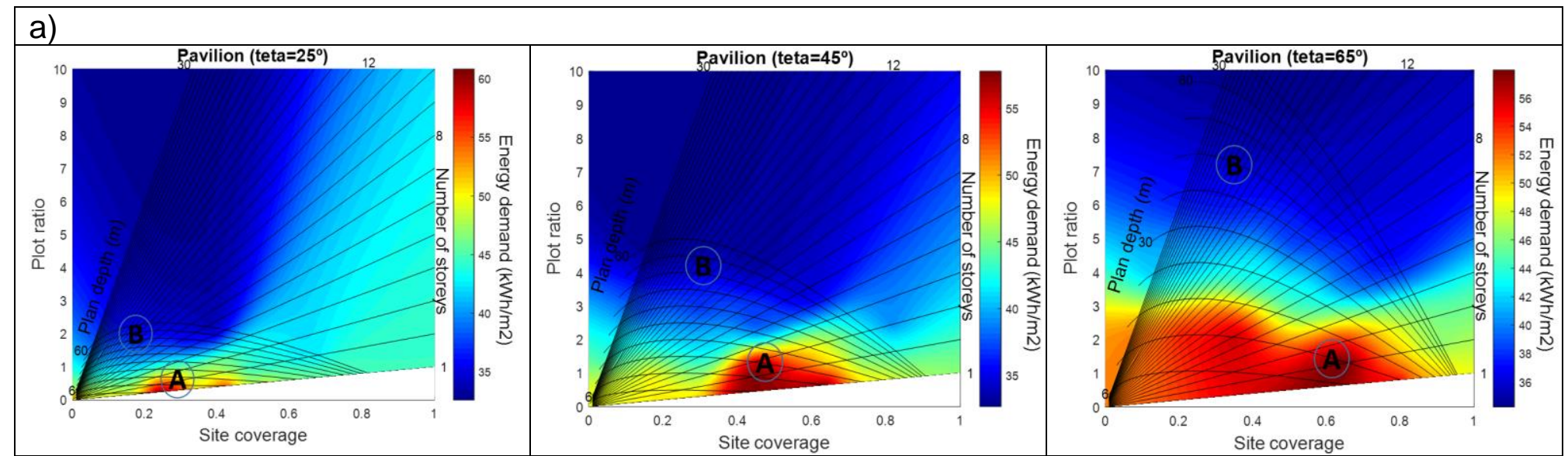

b)
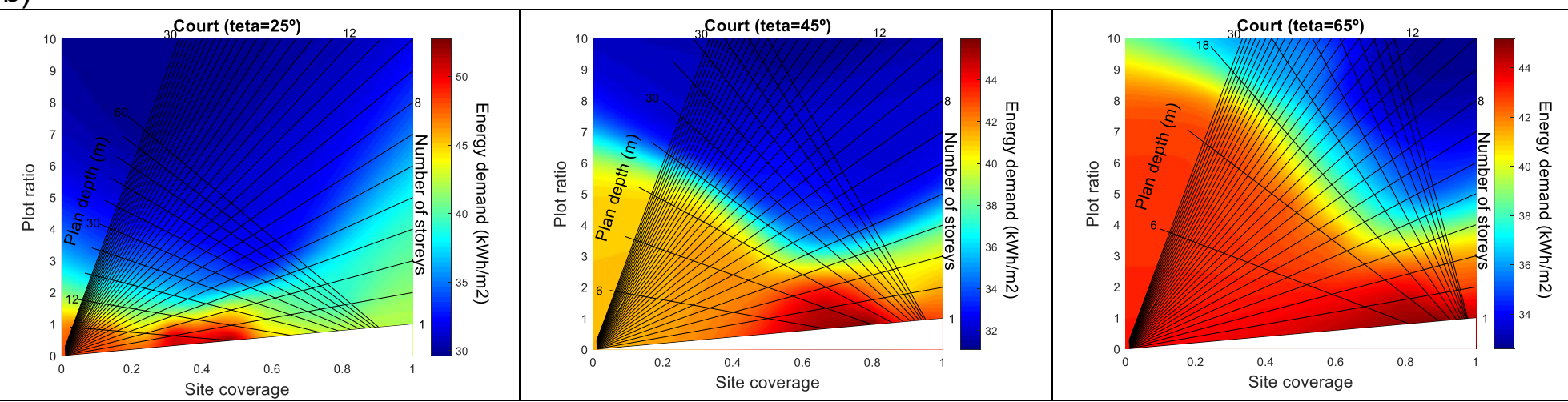

c) 


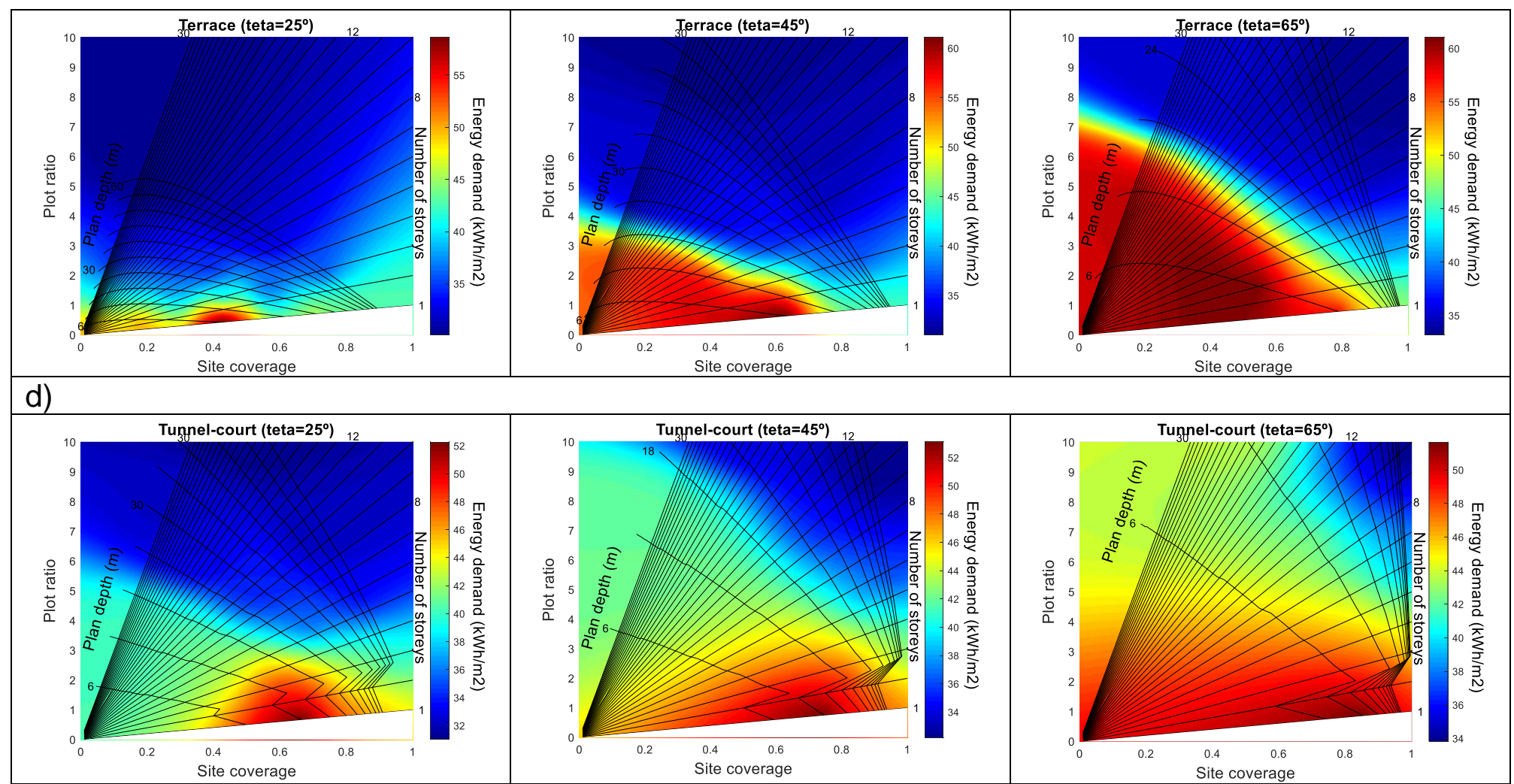

228 Figure 5: Correlation of building energy demand with urban built form and density considering cut-off

229 angles of $\theta=25^{\circ}, \theta=45^{\circ}$ and $\theta=65^{\circ}$ for a) pavilion; b) court; c) terrace; d) tunnel-court built forms

230 The horizontal axis of Figure 5 indicates site coverage with the vertical axis representing plot ratio.

231 The diagonal lines emanating from the origin indicates the number of storeys ( $n$ ), starting from 1-storey

232 (the line with the lowest slope) to 30-storeys (the line with the highest slope). The lines spreading from

233 bottom-right to top-left represent plan depth $(\mathrm{x})$ starting from $6 \mathrm{~m}$ and extending to $60 \mathrm{~m}$ depths. The

234 peculiar nature of tunnel-court is a result of the difference between one/two-storey building plans and

235 those with more than two-storeys. This creates an unusual change in the direction of the lines of plan

236 depth [28]. This is because one/two-storey buildings are not high enough to cover the roads, and hence

237 the site coverage and plot ratio are considerably lower than the buildings with a greater number of

238 storeys.

239 It can be seen from all cases that urban built areas with low-rise buildings (number of storeys up

240 to maximum four) and low plan depths (up to $24 \mathrm{~m}$ ) represent worst-case scenarios regarding energy

241 consumption (e.g. point $A$ ). This area of the graph, shown in dark red, represents building plans with

242 the highest energy consumption per square metre. Conversely, urban built areas with a higher number

243 of storeys [80] and plan depths [11] demonstrate the lowest energy consumption per unit area (e.g.

244 point $B$ ) indicated in dark blue. As an example, the energy demand at point $A$ is $58 \mathrm{kWh} / \mathrm{m} 2 / y e a r$, which

245 is a 2-storey building with $12 \mathrm{~m}$ plan depth, while it is only $34 \mathrm{kWh} / \mathrm{m} 2 /$ year at point $B$, which is a 20- 
storey building with $48 \mathrm{~m}$ plan depth. The $52 \%$ difference demonstrates the significant influence of

247 urban density on building energy demand [81].

248 The main contributor to these findings is that buildings with a lower surface to volume ratios

249 demand lower amounts of energy per floor area [80] because of lower energy loss from their envelope

250 [25]. This ratio is smaller for buildings with greater plan depths and taller buildings [10]. The results

251 emphasise the greater significance of plan depth on energy demand compared with the influence of

252 building height. This may be due to the $\mathrm{UHI}$ effect that is more dominant in lower floors due to the

253 relative closeness to the ground. One may therefore conclude that 'shorter and fatter' buildings, with

254 high site coverage, are more significantly affected by the UHI effect [21]. Moreover, in reality, lower air

255 temperatures and higher wind speeds at higher elevations result in increased heating loads [82].

256 However, this feature has not been considered here as it requires detailed CFD analysis.

257 It can also be seen from Figure 5 that the buildings sited in built areas with higher plot ratios are

258 more energy efficient. Similar results have been reported by Rode, Keim [20]. An important observation

259 from the graphs is that the term 'high density' is too vague to be used for urban energy analysis studies,

260 although it has been previously adopted in previous publications [83, 84]. An example of the ambiguity

261 can be seen from the areas of the graphs that show high site coverage but low plot ratio values (e.g.

262 point A) and vice versa. It proves that it certainly depends on the choice of density indicators to call an

263 urban area 'high density'.

264

\subsection{Impact of cut-off angle on building energy demand}

265

To investigate the influence of cut-off angle on building energy demand, building plans with similar

266 geometry but different cut-off angles are compared. Figure 6 shows a plan of pavilion buildings with

267 three different cut-off angles of $25^{\circ}, 45^{\circ}, 65^{\circ}$ resulting in different gaps between buildings. For each

268 simulation, the number of floors and plan depth are kept constant, while the cut-off angle is changed.

(a)

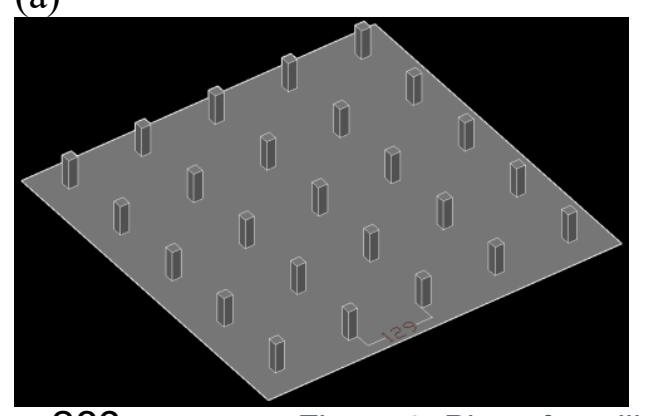

(b)

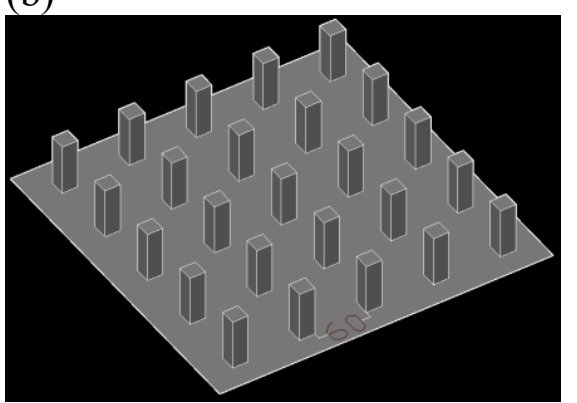

(c)

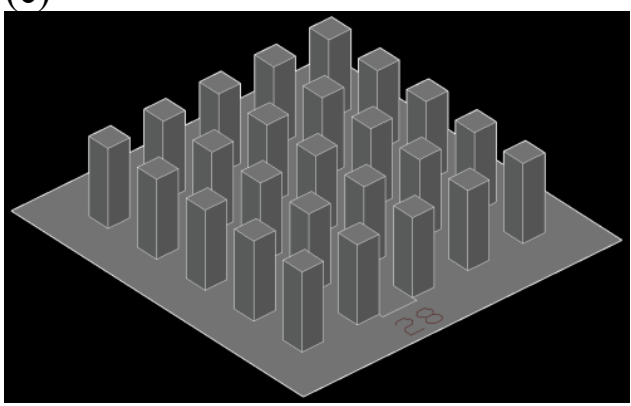


The results are shown in Figure 7, where each bar represents the annual energy per square metre

271 of floor area. It can be seen that buildings with higher cut-off angles, which means higher density (both

272 site coverage and plot ratio), consume more energy. Steemers [4] has reported similar results when

273 analysing energy demand of both residential and non-domestic buildings. The findings suggest that

274 regardless of the built form the energy demand of buildings is the highest for the built environment with

275 a cut-off angle of $65^{\circ}$, while it is the lowest for a cut-off angle of $25^{\circ}$. For instance, for buildings with plan

276 depths of $24 \mathrm{~m}$ and six storeys, energy demand is 40,41 and $44\left(\mathrm{kWh} / \mathrm{m}^{2}\right)$ for $\theta=25^{\circ}, \theta=45^{\circ}$ and $\theta=65^{\circ}$,

277 respectively. Considering urban 'energy' planning targets for London, this may encourage built areas

278 to have lower cut-off angles by increasing the distances between buildings. However, it should be noted

279 that other factors of urban planning such as mobility, land use, rents/land price, outdoor thermal comfort

280 and ecological footprint have not been considered and could ultimately influence the outcomes. For

281 instance, an extremely dense built environment may cause a negative effect on the outdoor thermal

282 comfort, while its intensity may depend on the climatic conditions. The study does nevertheless provide

283 mechanisms to identify the most effective/efficient starting point.
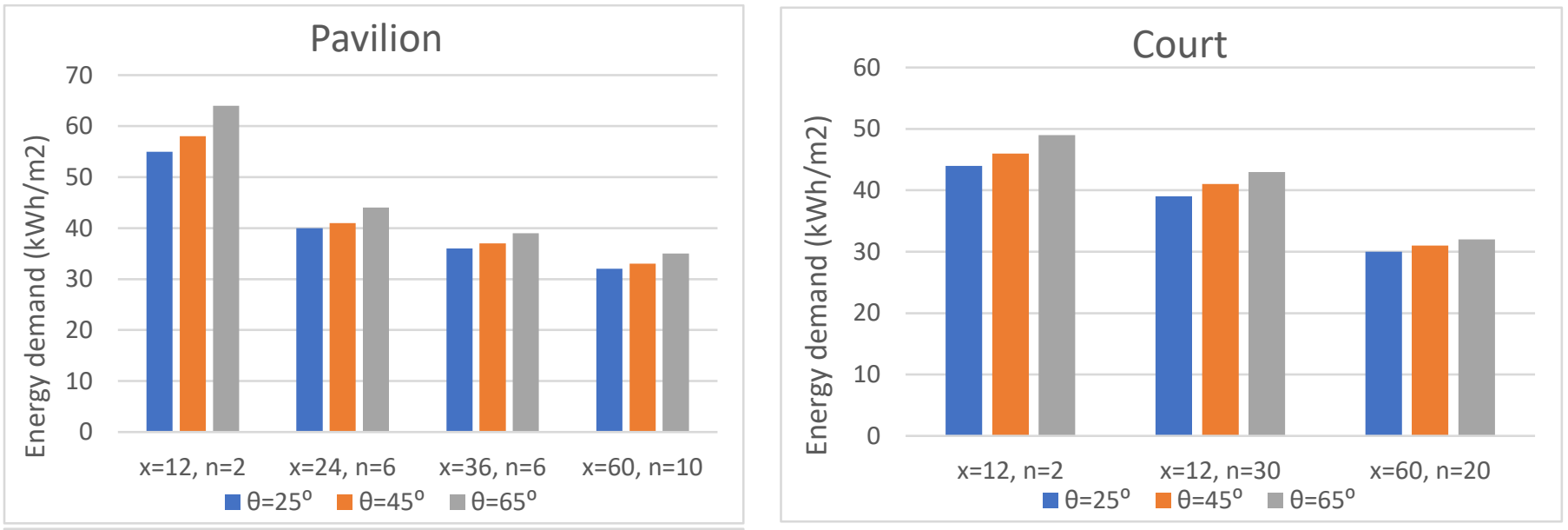

80

Terrace

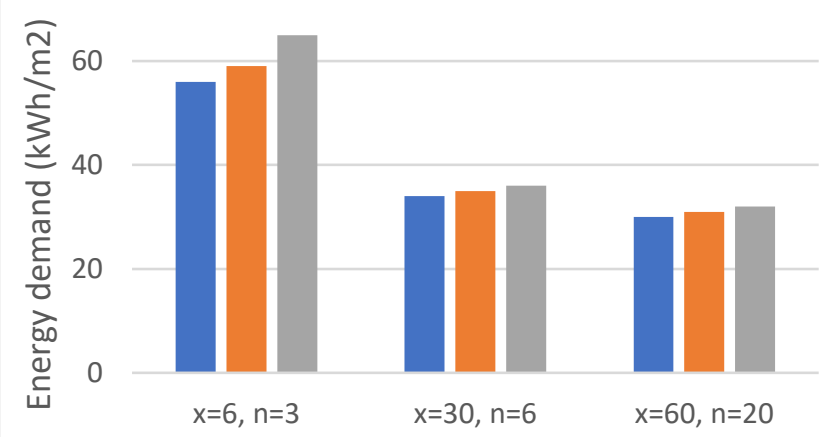

$\because \theta=25^{\circ} \quad \theta=45^{\circ} \quad \theta=65^{\circ}$

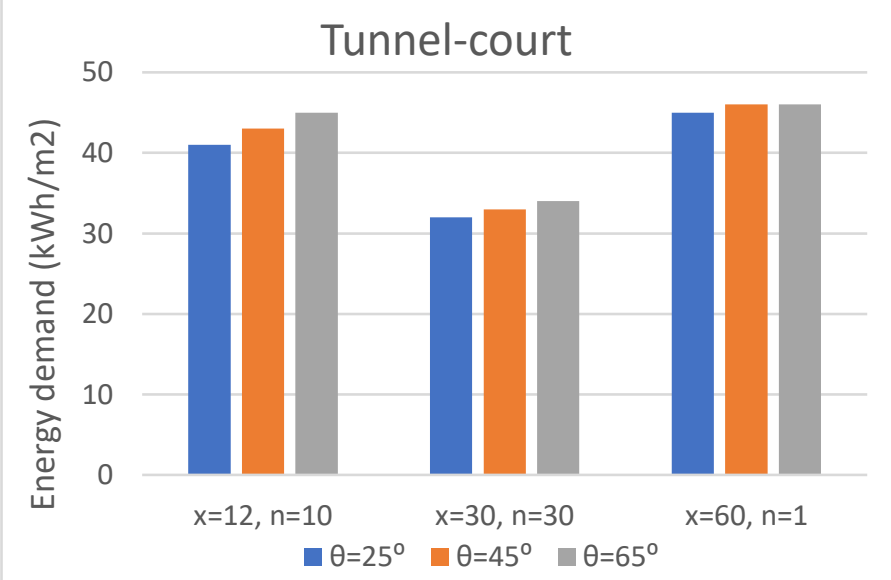

Figure 7: Comparison of the annual energy demand of building plans with a similar number of storeys

$(n)$ and plan depths $(x)$, but different cut-off angles $(\theta)$ 
The main reasons for this outcome are the altering of the shadowing effect and radiative interreflection between buildings in the form of short/long-wave radiation [58]. Building plans with higher 288 cut-off angles shield a bigger portion of sunlight being received by other buildings [47]. It not only reduces the solar gain through glazing but also decreases the amount of energy stored in building thermal mass which can result in higher heating energy demand [26]

This is a counter-example of the theory that promotes high-density urban developments are more energy-efficient than disperse areas [12,33]. Moreover, the optimum compactness of urban layout is profoundly dependant on climatic conditions [10]. For instance, higher density is beneficial in hot dry 294 climates to prevent excessive solar gains to reduce cooling loads [21]. Residential buildings in the UK will most probably need to be cooled in future due to higher temperatures as a result of climate change. This can consequently cause 'built form drift' for future developments even in temperate climates.

The results show that the influence of cut-off angle on the building energy demand diminishes with increasing plan depth. As shown in Figure 7, for buildings with long plan depths (e.g. x=60 m), building energy demand is less sensitive to cut-off angle compared to buildings with short plan depth (e.g. $x=12$ $\mathrm{m})$. The mitigating effect of plan depth on the sensitivity of heating energy demand to variation of cutoff angle is more significant in the case of tunnel-court form. It can be seen from Figure 7 that the impact of different cut-off angles from $65^{\circ}$ to $45^{\circ}$ in the tunnel-court form with $60 \mathrm{~m}$ plan depth is neutralized and the buildings indicate the same heating energy demand per $\mathrm{m}^{2}$. This is attributed to the fact that greater depth buildings possess a larger space. Therefore, their heating requirements are less affected by the surface area around the envelope, which is sensitive to external variables such as cut-off angle. Building height does not have as significant an impact as building depth because increasing height increases the area of the external walls, while increasing plan depth increases roof surface area. Increasing external surface area increases the sensitivity of thermal behaviour of the building to the external environment due to larger glazed areas and exchanging inter-reflected radiation with adjacent surfaces. Notably, different cut-off angles can influence important parameters such as the daylight availability

311 of buildings and consequently artificial lighting energy demand. Its impact on lighting energy demand is 312 not explicitly included in this study since artificial lighting energy is a minor contributor to the total energy demand of residential buildings, accounting for around $3 \%$ of the total load in the UK [67]. 
Having obtained the heating and electricity demands of buildings, the ratio of heating energy to electricity energy demand is now investigated. Electricity consumption is composed of normal appliance loads shown in Table 1 plus lighting. The results indicate that this ratio is larger, by a factor up to 2.5

318 for buildings with a lower number of storeys and smaller plan depths, while it gradually decreases by increasing these variables. The minimum value of the ratio is 0.65 , for high-rise buildings with large plan 320 depth, see (2).

$$
0.65 \leq \frac{\text { Heating energy demand }}{\text { Electricity consumption }} \leq 2.5
$$

This demonstrates that in buildings with the smaller floor area, heating energy demand dominates electricity energy demand. Conversely, in buildings with greater floor area (taller and wider), electricity energy demand becomes higher than the heating energy demand. This is because heating energy demand per unit area is reduced for larger buildings with a lower surface to volume ratio [85], and is dependent on the thermal properties of the envelope, specifically the U-values of exposed surfaces. For super-insulated envelopes where the heat loss through the fabric is negligible the amplitude of change of the ratio given by (2) is smaller. Unlike heating demand, electricity energy is estimated based on the consumption per square metre of floor area.

In conclusion, although urban built form and density have an impact on the heating energy demand of a building, they do not show a significant effect on electricity energy demand [82]—note: this assumes heating energy is predominantly provided by gas, while if heating is provided by electricity, the corresponding consumption would certainly be affected by built form and density. Moreover, appliances such as fans and pumps are excluded. Presence of ventilation fan can increase electricity consumption in buildings with long plan depth.

\subsection{Solar energy potential in London}

Using the same geometrical models, the impact of PV energy generation is now investigated. The value of Energy Equity (1) is used as a relative metric and is superimposed on the Form Signature graphs for each built form, as given in Figure 8 . 

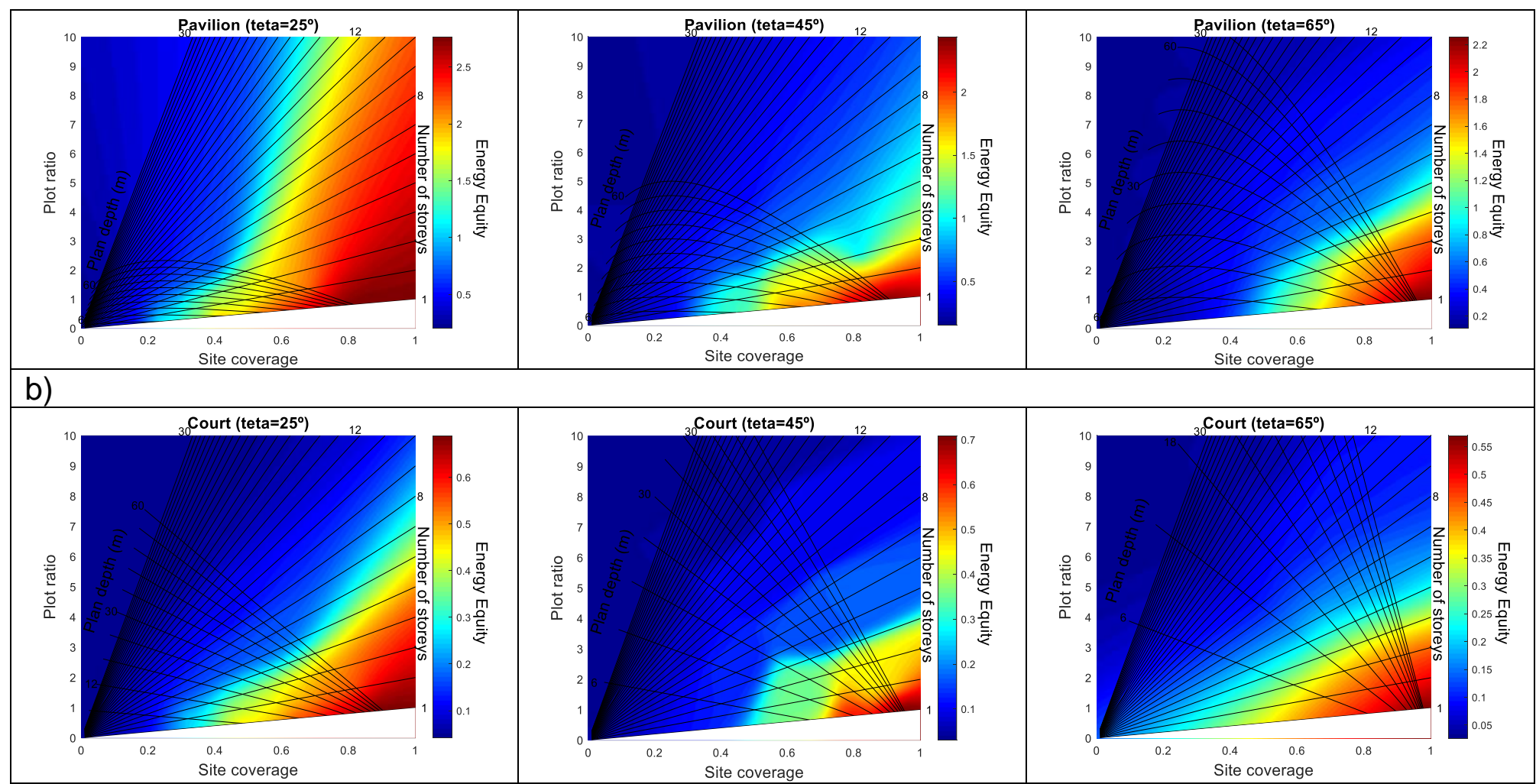

C)
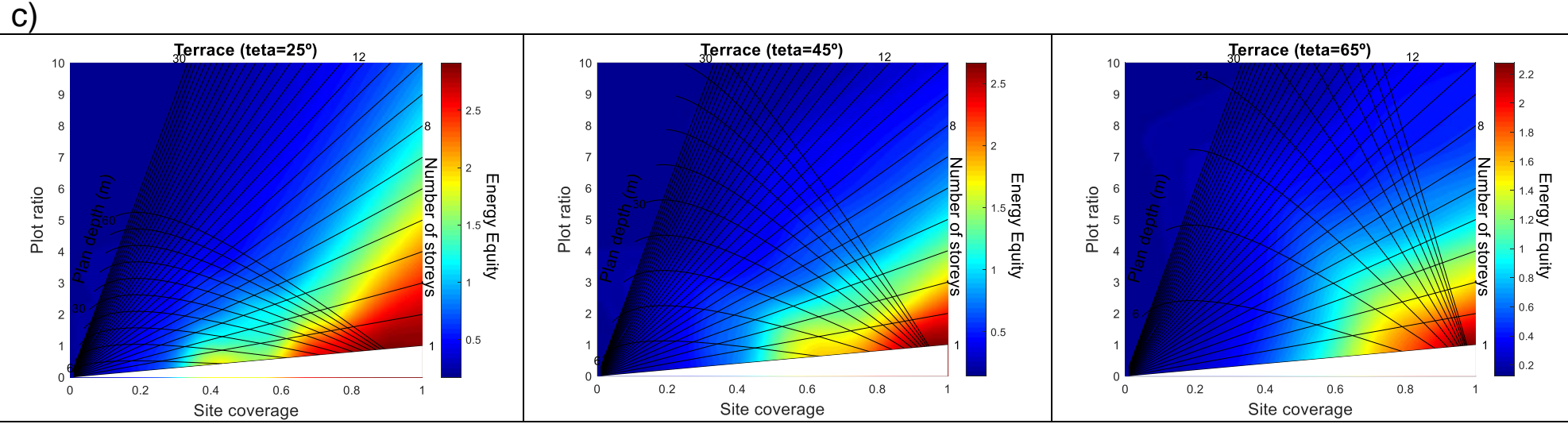

d)
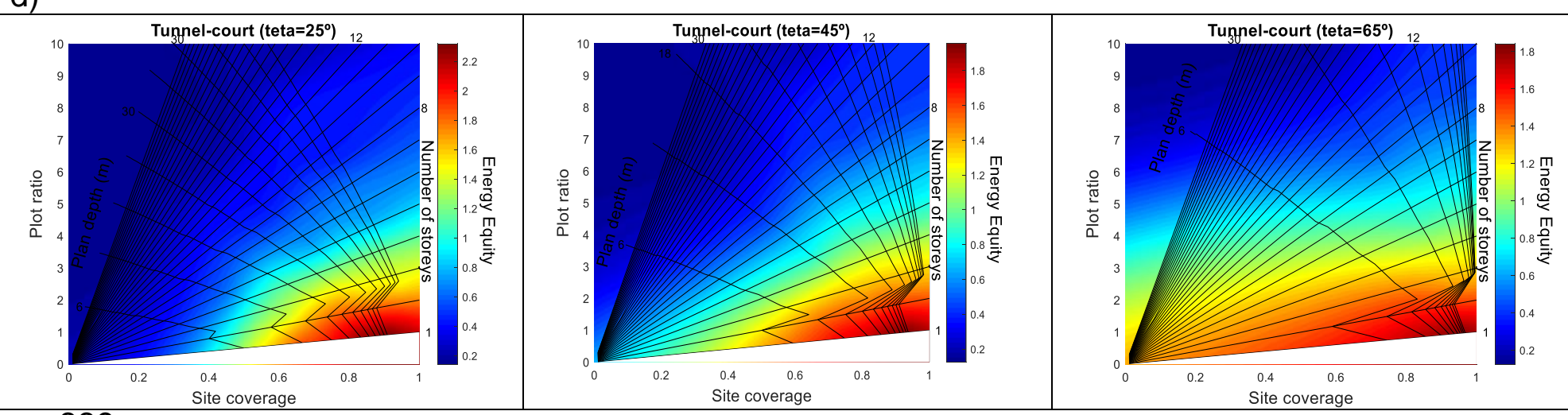

339 Figure 8: Correlation of Energy Equity indicator with urban built form and density a) pavilion; b) court;

c) terrace; d) tunnel-court

341 From Figure 8, built areas with greater plan depths and lower number of storeys possess greater

342 potential for solar energy generation (shown in red and orange). It means 'shorter, more squat' buildings

343 are the most appropriate for increasing the ratio of PV generation to building energy demand. This 
corresponds to high values of site coverage but low values of plot ratio that can neither be called high density nor low density urban development. This is comparable with the outcomes of studies by [15, 19].

It can be seen that, contrary to the results of Figure 5, high-rise buildings show poorer energy performance when PV energy generation is taken into consideration. It suggests that the consideration for geometry and density of the built environment should be different for future urban developments if the utilisation of renewable energy potential, specifically solar energy [86], is a priority. It should be noted that if façade PVs are considered in addition to roof PVs, by increasing compactness in a neighbourhood, the potential of PV generation on facades is significantly reduced [15]. Meanwhile, lower site coverage would allow better solar access to façade PVs [19], though average building height has a higher impact [86]. Finally, layout and orientation are very influential on façade PVs compared to roof PVs [14].

An interesting application of the findings is the ability to determine the appropriate urban density that buildings can be energetically self-sufficient (indicated in bright blue representing unity Energy

358 Equity). In the red areas where $E_{\text {equity }} 1$ the building generates more energy than is demanded which can be exported to the national grid or be stored for purposes such as charging electric vehicles [87], or provision of electricity in times of energy deficit (e.g. peak times). It is more difficult to achieve building energy self-sufficiency in court form in comparison to pavilion form, although pavilion buildings consume more energy per square metre of floor area compared to court buildings. That is because court buildings acquire higher density (because of its form and geometry), which means there is less roof area compared to the total floor area for PV installation.

365

366

\section{Discussion}

In the following the most suitable urban built forms for London are proposed based on using either similar geometrical parameters or on similar densities.

\subsection{Comparison of the energy performance of different built forms with similar geometrical variables}

The Form Signature graphs have established relationships of energy with density for each urban built form. Here, building plans composed of the different built forms, but with similar cut-off angles, plan depths and number of storeys, are compared. The results are shown in Figure 9. 


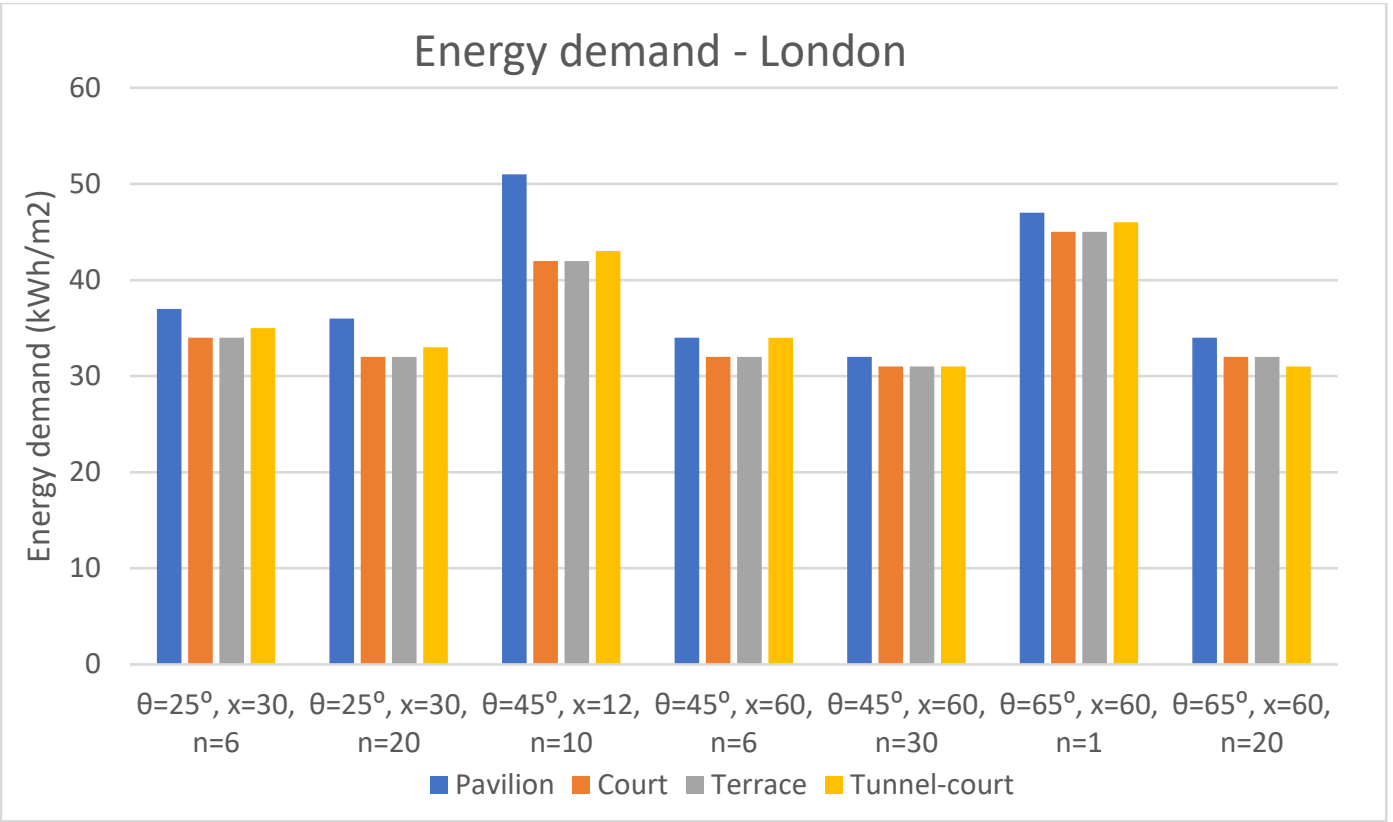

Figure 9: Comparison of the energy demand of the built forms with the same cut-off angles, plan depths and number of storeys in London

It can be seen that in all cases pavilion built form shows the highest energy demand per square metre, while court and terrace built forms are the most energy-efficient. For instance, a pavilion built 378 district composed of 20 storey buildings with a cut-off angle of $25^{\circ}$ and plan depth of $30 \mathrm{~m}$ demands 36 $\mathrm{kWh} / \mathrm{m}^{2} /$ year of energy, while both terrace and court forms require approximately $32 \mathrm{kWh} / \mathrm{m}^{2} / \mathrm{year}$ of energy (with a negligible difference). The equivalent energy demand of tunnel-court form buildings is $33 \mathrm{kWh} / \mathrm{m}^{2} /$ year. Hence, the terrace and court forms are almost $12 \%$ more energy-efficient than pavilion form, while they are only $3 \%$ more energy-efficient than tunnel-court form. This is due to the higher surface to volume ratio of pavilion compared to terrace and court forms. Also, the surface to volume ratios of terrace and court forms differ only slightly [28] resulting in negligible energy demand difference. Although the surface to volume ratio of tunnel-court is lower than the others, its energy demand is higher than terrace and court forms. This shows the influence of built form on energy demand by altering the parameters such as shadowing effect, wind direction and inter-reflection between the surfaces, which can change the microclimatic conditions.

As the building envelope becomes more energy-efficient due to increased level of insulation, the surface/volume ratio becomes less important [88]. However, the lower quality of the building envelope which can be seen in the majority of existing buildings could result in greater differences compared with that shown in Figure 9. It reflects the higher influence of built form on energy demand of low standard buildings. 
If building solar energy generation is considered in addition to energy demand, as shown in Figure 10, the outcomes can be significantly affected. The results from the selected cases indicate better performance of tunnel-court form while pavilion is the worst performer, having the lowest Energy Equity value.

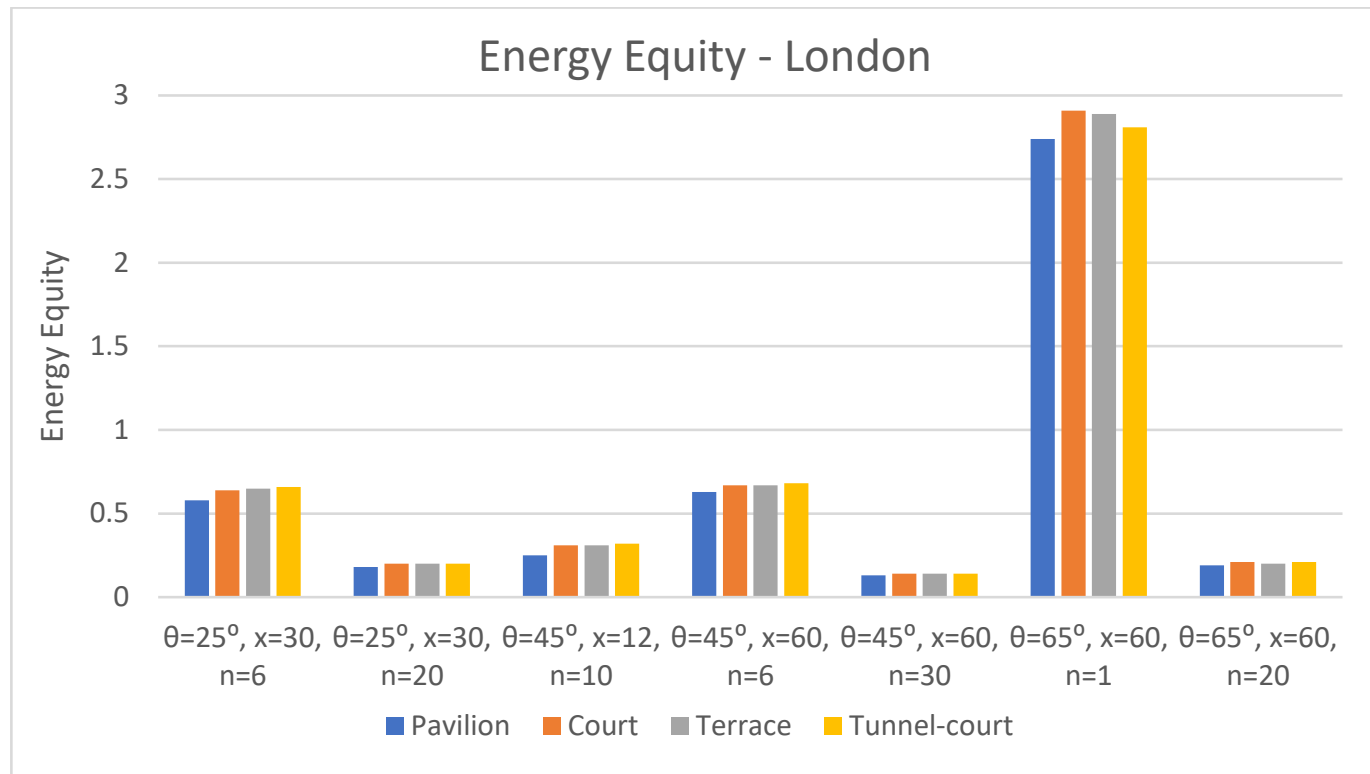

Figure 10: Comparison of Energy Equity of the built forms with the same cut-off angles, plan depths and number of storeys in London

Low values of Energy Equity are advocated by a small roof area of building compared to its total energy demand. It corresponds to the area of the roof to floor area ratio [17]. From Figure 10, one can see that this indicator is the lowest for pavilion built form and is relatively high for a tunnel-court form because of its large effective roof area (it covers some parts of the roads (Figure 2) for PV installation.

\subsection{Comparison of the energy performance of different built forms with similar density}

Thus far, built forms with equal geometrical variables (i.e. cut-off angle, plan depth and number of storeys) have been considered. However, the equity of parameters does not directly translate to equivalent urban density. For instance, for the first group of data shown in Figure 9 and Figure 10, the density (site coverage and plot ratio) of different built forms are shown in Table 2 .

\begin{tabular}{|c|c|c|c|c|}
\hline$\theta=25^{\circ}, x=30, n=6$ & Pavilion & Court & Terrace & Tunnel-court \\
\hline Site coverage & 0.191 & 0.437 & 0.383 & 0.683 \\
\hline Plot ratio & 1.147 & 2.624 & 2.296 & 3.845 \\
\hline $\begin{array}{c}\text { Energy demand } \\
\text { (kWh/m/year) }\end{array}$ & 37 & 34 & 34 & 35 \\
\hline Energy Equity & 0.58 & 0.64 & 0.65 & 0.66 \\
\hline
\end{tabular}



geometrical variables

Whilst all built forms have the same cut-off angle, plan depth and number of storeys, the site

414 coverage and plot ratios are different. Pavilion has the lowest density, highest energy demand and

415 lowest Energy Equity, while tunnel-court has the highest density but with medium energy demand and

416 highest Energy Equity. Court and terrace forms have medium density, lowest energy demand and

417 medium Energy Equity. The last two cases depict similar energy performance, while the density of court

418 built form is higher than terrace. This comparison suggests that, for climatic conditions typical of London,

419 urban areas with court built form can reach higher density compared with terrace built forms having 420 similar energy performance. This indicates that if the urban policy is aiming for the highest density, court 421 built form should be chosen rather than a terrace built form from an energy efficiency perspective.

For a fixed density, built forms can now also be compared with respect to geometrical variations.

423 For instance, for site coverage $\simeq 0.45$, and plot ratio $\simeq 4.5$, the geometrical variables of the built forms

424 and their energy performance indicators are summarised in Table 3.

\begin{tabular}{|c|c|c|c|c|}
\hline $\begin{array}{c}\text { Site coverage } \simeq 0.45 \\
\text { Plot ratio } \simeq 4.5\end{array}$ & Pavilion & Court & Terrace & Tunnel-court \\
\hline Cut-off angle & $\theta=45^{\circ}$ & $\theta=45^{\circ}$ & $\theta=45^{\circ}$ & $\theta=45^{\circ}$ \\
\hline Plan depth $(\mathrm{m})$ & $\mathrm{x}=60$ & $\mathrm{x}=24$ & $\mathrm{x}=30$ & $\mathrm{x}=12$ \\
\hline Number of storeys & $\mathrm{n}=10$ & $\mathrm{n}=10$ & $\mathrm{n}=10$ & $\mathrm{n}=10$ \\
\hline $\begin{array}{c}\text { Energy demand } \\
\text { (kWh/m²/year) }\end{array}$ & 33 & 35 & 34 & 43 \\
\hline Energy Equity & 0.39 & 0.37 & 0.38 & 0.32 \\
\hline
\end{tabular}

Table 3: Comparison of the energy performance of different built forms with similar density

Table 3 shows that, having the same urban density, pavilion built form has the best energy performance with the lowest energy demand and highest Energy Equity. Tunnel-court form shows the worst energy performance compared to others with the same density. The main reason behind this is the greater plan depth of pavilion built form $(\mathrm{x}=60 \mathrm{~m})$ with respect to the other cases. As was established earlier in section 3, buildings with greater plan depths have lower energy demand and higher Energy 431 Equity.

432 It should be noted that all the cases depicted in Table 3 have a cut-off angle of $45^{\circ}$ and the only geometrical variable that changes their density is plan depth. However, the same density with the same

434 built form can be achieved by changing the cut-off angle. In this case, if the cut-off angle increases, plan depth must be decreased (and vice versa) to preserve density. Therefore, the same built form with 
436 the same density may have different energy performance depending on the geometry of urban built 437 area. Table 4 shows exemplar scenarios for two court built areas with similar densities.

\begin{tabular}{|c|c|c|c|c|c|c|c|}
\hline & $\begin{array}{c}\text { Site } \\
\text { coverage }\end{array}$ & $\begin{array}{c}\text { Plot } \\
\text { ratio }\end{array}$ & $\begin{array}{c}\text { Cut-off } \\
\text { angle }\end{array}$ & $\begin{array}{c}\text { Plan depth } \\
(\mathrm{m})\end{array}$ & $\begin{array}{c}\text { Number of } \\
\text { storeys }\end{array}$ & $\begin{array}{c}\text { Energy demand } \\
\left(\mathrm{kWh} / \mathrm{m}^{2} / \text { year }\right)\end{array}$ & $\begin{array}{c}\text { Energy } \\
\text { Equity }\end{array}$ \\
\hline Court 1 & $\simeq 0.45$ & $\simeq 4.5$ & $\theta=45^{\circ}$ & $\mathrm{x}=24$ & $\mathrm{n}=10$ & 35 & 0.37 \\
\hline Court 2 & $\simeq 0.45$ & $\simeq 4.5$ & $\theta=65^{\circ}$ & $\mathrm{x}=12$ & $\mathrm{n}=10$ & 44 & 0.29 \\
\hline
\end{tabular}

$438 \quad$ Table 4: Exemplar scenarios for court built forms with similar densities but different geometrical

variables and energy performance

440 It can be seen that although they have the same density, their energy performance is significantly

441 different. The energy demand of the Court 1 is $23 \%$ less than the Court 2 while its Energy Equity is $24 \%$

442 higher. The difference shows the importance of geometry for achieving target densities. Court 2 has a

443 bigger cut-off angle and smaller plan depth that result in higher energy demand and lower Energy

444 Equity. Therefore, a built form with the same density may acquire very different energy performance

445 which must be taken into consideration for urban planning and policy-making purposes.

446 In conclusion, urban energy planning can be set according to two different policies, as shown in

447 Figure 11. Keeping geometrical parameters constant, tunnel-court built form is the most energetically

448 sustainable built form for London because its ratio of renewable energy generation to total energy

449 demand is the highest. For constant density scenarios, pavilion built form is the most energetically

450 sustainable for London because it not only conserves more energy in its envelope but it also has a

451 higher potential for renewable energy generation. In this scenario, the tunnel-court built form shows the

452 worst energy performance.

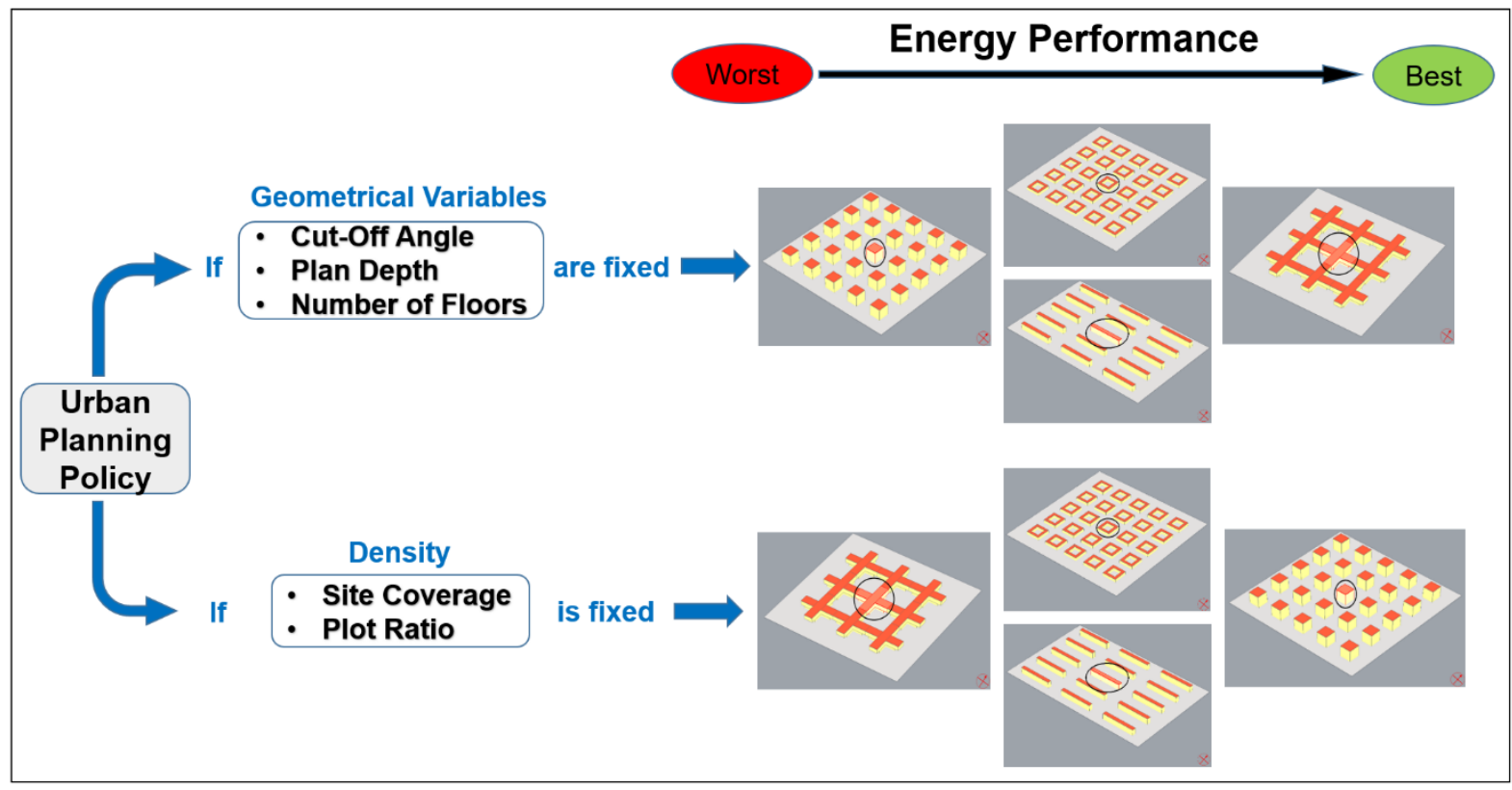

Figure 11: Ranking the energy performance of urban built forms according to two different urban planning policies for London climate 
457 depend on the policy targets. The findings of the study provide urban planning guidelines demonstrating

458 the simultaneous correlation of urban geometrical variables and the two most popular density indicators.

459 It provides the opportunity for urban planners to decide on the most energy-efficient built form and 460 density following urban planning policies. If the policy fixes one, two or all the geometrical variables, by 461 looking at the Form Signature graphs and changing density in the permitted areas of the chosen graph 462 (according to the policy), the most energy-efficient site plan with specific density can be selected. While 463 if the policy fixes the density of the site plan, the most appropriate built form can be selected by changing 464 geometrical variables.

\section{Conclusions}

466 This study proposes a novel urban energy planning tool to provide recommendations of the most 467 appropriate energy-efficient built form and density for temperate climatic conditions. This is achieved 468 by demonstrating the simultaneous correlation between building energy demand and PV energy 469 generation with urban built form and density. Adaptation of the two popular urban density indicators 470 shows comprehensiveness of the analysis that fills the gap in the knowledge for making a comparison 471 between the results of similar studies.

472 The study initially shows that it is critical to use the terms 'high density' or 'low density' 473 appropriately, as it depends on the choice of density indicator, and has included the use of Form

474 Signature to illustrate the simultaneous change of two density indicators and demonstrate that some 475 areas corresponding to high values of site coverage have low plot ratios, and vice versa.

476 The results also show the significant effect of plan depth and the number of storeys on the trend 477 of building energy performance. Specifically, buildings with greater plan depths and number of stories 478 are the best for minimum energy demand that corresponds to greater plot ratios. Lowering cut-off angles 479 (which means higher density) reduces the heating demand regardless of the built form for London 480 climatic conditions. The heating energy demand of buildings with larger plan depths is less influenced 481 by cut-off angle variations compared with small depth buildings. This is due to the larger space of the 482 deep buildings that make their energy demand less influenced by the external environment.

483 The magnitude of heating energy demand compared to electricity demand is shown to be greater 484 in a taller and wider building. These results demonstrate the significant effect that built form has on 
heating energy demand and rather the negligible effect it has on electricity energy demand for buildings heated by gas.

If $\mathrm{PV}$ panels are to be installed on roofs, buildings with a lower number of storeys and greater plan depths (which corresponds to high site coverage and low plot ratio) have better energy performance

489 due to their higher potential for harvesting solar energy, as opposed to 'taller and narrower' buildings. 490 However, this conclusion could be mitigated if façade PVs are considered in addition to roof PVs. A 491 lower number of storeys means less plot ratio and a smaller number of occupants which reduce energy consumption per building. It facilitates building energy self-sufficiency by making a balance between energy demand and supply of the building using Energy Equity indicator.

A comparison of the relative energy performance of built forms with similar geometrical variables shows that terrace and court forms have the lowest energy demand and pavilion the highest. However, when solar energy generation is considered in addition to energy demand, tunnel-court form provides

497 the best total energy performance by having the highest value of Energy Equity. Comparing the built forms with similar densities, pavilion built form is the most energy-efficient form while tunnel-court's performance is the worst. Furthermore, it is possible to have a constant density for any of the built forms but with different energy performance depending on the value of the geometrical variables. Among the main findings of this study is that when considering building energy performance as the main criteria, the best built form for London is either pavilion or tunnel-court built form, depending on the urban

503 planning policies. Therefore, it is highly recommended that to make a true comparison between the energy performance of different urban built forms, their urban density and geometrical variables must be analysed simultaneously.

506 These conclusions are valid under the assumptions and limited scopes of this study. The inclusion 507 of other aspects of urban planning such as mobility, land-use, housing price and outdoor thermal 508 comfort, along with the limitations of modelling with CitySim (e.g. single thermal zone consideration) 509 may cause alteration in the conclusions.

\section{Future developments}

511 The presented research is currently being expanded to investigate built forms for alternative 512 climatic conditions and for the inclusion of characteristics of other sustainable sources (e.g. domestic 513 wind turbines) which can be added to the proposed Form Signature diagrams. Moreover, projections

514 of the impact of future climatic conditions on current built form solutions are also being investigated. 


\section{Acknowledgements}

517 The authors would like to thank Dr Phil Ashheton from the Math and Statistics Centre (Mash) of the

518 University of Lincoln for his contribution to developing the MATLAB codes required for computer

519 simulations.

520 This research did not receive any specific grant from funding agencies in the public, commercial, or not-

521 for-profit sectors.

522

1. United Nations. Climate Action [Available from: www.un.org/en/climatechange/citiespollution.shtml.

2. United Nations. World Urbanization Prospects: The 2014 Revision, Highlights. United Nations, Affairs DoEaS; 2014.

3. Rickwood P, Glazebrook G, Searle G. Urban structure and energy - a review. Urban policy and research. 2008;26(1):57-81.

4. Steemers K. Energy and the city: density, buildings and transport. Energy and buildings. 2003;35(1):3-14.

5. Lee G, Jeong Y. Impact of Urban and Building Form and Microclimate on the Energy Consumption of Buildings-Based on Statistical Analysis. Journal of Asian Architecture and Building Engineering. 2017;16(3):565-72.

6. Güneralp B, Zhou Y, Ürge-Vorsatz D, Gupta M, Yu S, Patel PL, et al. Global scenarios of urban density and its impacts on building energy use through 2050. Proceedings of the National Academy of Sciences. 2017:201606035.

7. Jabareen YR. Sustainable urban forms: Their typologies, models, and concepts. Journal of planning education and research. 2006;26(1):38-52.

8. Silva M, Oliveira V, Leal V. Urban Form and Energy Demand: A Review of Energy-relevant Urban Attributes. Journal of Planning Literature. 2017:0885412217706900.

9. Bhiwapurkar P, editor Determinants of Urban Energy Use: Density and Urban Form. ARCC Conference Repository; 2014.

10. Resch E, Bohne RA, Kvamsdal T, Lohne J. Impact of urban density and building height on energy use in cities. Energy Procedia. 2016;96:800-14.

11. Steadman P, Hamilton I, Evans S. Energy and urban built form: an empirical and statistical approach. Building Research \& Information. 2014;42(1):17-31.

12. Boukarta S, Berezowska E. Exploring the Energy Implication of Urban Density in Residential Buildings. Journal of Applied Engineering Sciences. 2017;7(1):7-14.

13. Ewing R, Rong $F$. The impact of urban form on US residential energy use. Housing policy debate. 2008;19(1):1-30.

14. Hachem C, Athienitis A, Fazio P. Investigation of solar potential of housing units in different neighborhood designs. Energy and Buildings. 2011;43(9):2262-73.

15. Mohajeri N, Upadhyay G, Gudmundsson A, Assouline D, Kämpf J, Scartezzini J-L. Effects of urban compactness on solar energy potential. Renewable Energy. 2016;93:469-82.

16. Hargreaves A, Cheng V, Deshmukh S, Leach M, Steemers K. Forecasting how residential urban form affects the regional carbon savings and costs of retrofitting and decentralized energy supply. Applied Energy. 2017;186:549-61.

17. Byrd H, Ho A, Sharp B, Kumar-Nair N. Measuring the solar potential of a city and its implications for energy policy. Energy policy. 2013;61:944-52.

18. Echenique MH, Hargreaves AJ, Mitchell G, Namdeo A. Growing cities sustainably: does urban form really matter? Journal of the American Planning Association. 2012;78(2):121-37.

19. Cheng V, Steemers K, Montavon M, Compagnon R, editors. Urban form, density and solar potential. PLEA 2006; 2006.

20. Rode P, Keim C, Robazza G, Viejo P, Schofield J. Cities and energy: urban morphology and residential heat-energy demand. Environment and Planning B: Planning and Design. 2014;41(1):13862. 
21. Javanroodi K, Mahdavinejad M, Nik VM. Impacts of urban morphology on reducing cooling load and increasing ventilation potential in hot-arid climate. Applied Energy. 2018;231:714-46.

22. Javanroodi K, Nik VM. Impacts of Microclimate Conditions on the Energy Performance of Buildings in Urban Areas. Buildings. 2019;9(8):189.

23. Cheng V. Understanding density and high density. Designing High-Density Cities: Routledge; 2009. p. 37-51.

24. Steadman P. Building types and built forms: Troubador Publishing Ltd; 2014.

25. Ratti C, Baker N, Steemers K. Energy consumption and urban texture. Energy and buildings. 2005;37(7):762-76.

26. Coccolo S, Monna S, Kaempf JH, Mauree D, Scartezzini J-L. Energy demand and urban microclimate of old and new residential districts in a hot arid climate. 36th International Conference on Passive and Low Energy Architecture; Los Angeles2016.

27. Gordon IR, Mace A, Whitehead C. Defining, measuring and implementing density standards in London: London plan density research project 1. 2016 Density review. 2016.

28. Ahmadian E, Sodagar B, Mills G, Byrd H, Bingham C, Zolotas A. Sustainable cities: The relationships between urban built forms and density indicators. Cities. 2019;95.

29. Cao X, Dai X, Liu J. Building energy-consumption status worldwide and the state-of-the-art technologies for zero-energy buildings during the past decade. Energy and buildings. 2016;128:198213.

30. Ferrara M, Prunotto F, Rolfo A, Fabrizio E. Energy Demand and Supply Simultaneous Optimization to Design a Nearly Zero-Energy House. Applied Sciences. 2019;9(11):2261.

31. Kazas G, Fabrizio E, Perino M. Energy demand profile generation with detailed time resolution at an urban district scale: A reference building approach and case study. Applied Energy. 2017;193:24362 .

32. Murray P, Marquant J, Niffeler M, Mavromatidis G, Orehounig K. Optimal transformation strategies for buildings, neighbourhoods and districts to reach $\mathrm{CO} 2$ emission reduction targets. Energy and Buildings. 2020;207:109569.

33. Leng $\mathrm{H}, \mathrm{Ma} \mathrm{Y}$, Wong $\mathrm{NH}$, Ming $\mathrm{T}$. Urban morphology and building heating energy consumption: Evidence from Harbin, a severe cold region city. Energy and Buildings. 2020:110143.

34. You Y, Kim S. Revealing the mechanism of urban morphology affecting residential energy efficiency in Seoul, Korea. Sustainable cities and society. 2018;43:176-90.

35. Perera A, Coccolo S, Scartezzini J-L. The influence of urban form on the grid integration of renewable energy technologies and distributed energy systems. Scientific reports. 2019;9(1):1-14.

36. Waibel C, Evins R, Carmeliet J. Co-simulation and optimization of building geometry and multienergy systems: Interdependencies in energy supply, energy demand and solar potentials. Applied Energy. 2019;242:1661-82.

37. Berghauser Pont M, Haupt P. The Spacemate: density and the typomorphology of the urban fabric. Urbanism laboratory for cities and regions: progress of research issues in urbanism2007.

38. Emmanuel R, Steemers K. Connecting the realms of urban form, density and microclimate. Building Research \& Information. 2018;48(2):804-8.

39. CitySim. Kaemco; [Available from: www.kaemco.ch/download.php.

40. Le Guen M, Mosca L, Perera ATD, Coccolo S, Mohajeri N, Scartezzini J-L. Improving the energy sustainability of a Swiss village through building renovation and renewable energy integration. Energy and Buildings. 2018;158:906-23.

41. Moghadam ST, Coccolo S, Mutani G, Lombardi P, Scartezzini J-L, Mauree D. A new clustering and visualization method to evaluate urban heat energy planning scenarios. Cities. 2019;88:19-36.

42. Perera A, Coccolo S, Scartezzini J-L, Mauree D. Quantifying the impact of urban climate by extending the boundaries of urban energy system modeling. Applied Energy. 2018;222:847-60.

43. Coccolo S, Kämpf JH, Scartezzini J-L, editors. Design in the desert. A Bioclimatic project with urban energy modelling. Proceedings of building simulation; 2013.

44. Walter E, Kämpf JH, editors. A verification of CitySim results using the BESTEST and monitored consumption values. Proceedings of the 2nd Building Simulation Applications conference; 2015: Bozen-Bolzano University Press.

45. SAP. The government's standard assessment procedure for energy rating of dwellings. 2012.

46. Chan A. Effect of adjacent shading on the thermal performance of residential buildings in a subtropical region. Applied energy. 2012;92:516-22.

47. Nikoofard S, Ugursal VI, Beausoleil-Morrison I. Effect of external shading on household energy requirement for heating and cooling in Canada. Energy and buildings. 2011;43(7):1627-35. 
48. Ürge-Vorsatz D, Eyre N, Graham P, Harvey D, Hertwich E, Jiang Y, et al. Energy end-use: Buildings. Global Energy Assessment: Toward a Sustainable Future: Cambridge University Press; 2012. p. 649-760.

49. Creswell JW, Tashakkori A. Differing perspectives on mixed methods research. Sage Publications Sage CA: Los Angeles, CA; 2007.

50. March L. Elementary models of built forms. In: Martin L, March L, editors. Urban Space and Structures: Cambridge University Press; 1972. p. 55-96. analysis and an arid climate. Energy and buildings. 2003;35(1):49-59.

52. Elnokaly A, Ayoub M, Elseragy A. Parametric investigation of traditional vaulted roofs in hotarid climates. Renewable Energy. 2019;138:250-62.

53. Galante A, Torri M. A methodology for the energy performance classification of residential building stock on an urban scale. Energy and Buildings. 2012;48:211-9.

54. Ben H, Steemers K. Energy retrofit and occupant behaviour in protected housing: A case study of the Brunswick Centre in London. Energy and Buildings. 2014;80:120-30.

55. Park J, Kim H. A field study of occupant behavior and energy consumption in apartments with mechanical ventilation. Energy and buildings. 2012;50:19-25.

56. Sodagar B, Starkey D. The monitored performance of four social houses certified to the Code for Sustainable Homes Level 5. Energy and Buildings. 2016;110:245-56.

57. Berger M, Worlitschek J. The link between climate and thermal energy demand on national level: A case study on Switzerland. Energy and Buildings. 2019;202:109372.

58. CIBSE Guide F. Energy Efficiency in Buildings: CIBSE Guide F: Chartered Institution of Building Services Engineers; 2020.

59. Li Q, Quan SJ, Augenbroe G, Yang PP-J, Brown J, editors. Building energy modelling at urban scale: integration of reduced order energy model with geographical information. Building Simulation; 2015.

60. Dorer V, Allegrini J, Orehounig K, Moonen P, Upadhyay G, Kämpf J, et al. Modelling the urban microclimate and its impact on the energy demand of buildings and building clusters. Proceedings of BS. 2013;2013:3483-9.

61. Toparlar Y, Blocken B, Maiheu B, Van Heijst G. A review on the CFD analysis of urban microclimate. Renewable and Sustainable Energy Reviews. 2017;80:1613-40.

62. Shirzadi M, Naghashzadegan M, Mirzaei PA. Developing a framework for improvement of building thermal performance modeling under urban microclimate interactions. Sustainable Cities and Society. 2019;44:27-39.

63. Meteonorm. Meteotest; [Available from: https://meteonorm.com/en/.

64. Mauree D, Coccolo S, Kaempf J, Scartezzini J-L. Multi-scale modelling to evaluate building energy consumption at the neighbourhood scale. PloS one. 2017;12(9):e0183437.

65. Rubel F, Kottek M. Observed and projected climate shifts 1901-2100 depicted by world maps of the Köppen-Geiger climate classification. Meteorologische Zeitschrift. 2010;19(2):135-41.

66. World Population Review. London Population 2020: World Population Review; 2020 [Available from: https://worldpopulationreview.com/world-cities/london-population.

67. Palmer J, Cooper I. United Kingdom housing energy fact file. Department of Energy and Climate Change London; 2013.

68. Building Regulations. Approved Document Part F, Ventilation. Crown Copyright, London. 2010. 69. Building Regulations. The Building Regulations Part L1A, 2016, Conservation of fuel and power Approved Document. Publ by NBS, UK. 2016.

70. Ghisi E, Tinker JA, editors. Window sizes required for the energy efficiency of a building against window sizes required for view. Proceedings of the CIB World Building Congress, Toronto, Canada; 2004.

71. Feist W, Pfluger R, Kaufmann B, Schnieders J, Kah O. Passive house planning package 2007. Specifications for Quality Approved Passive Houses, Technical Information PHI-2007/1 (E), Darmstadt, Passivhaus Institut (December 2007). 2007.

72. ASHRAE Standard. Standard 62.1-2010 (2010). ventilation for acceptable indoor air quality, atlanta, ga. American Society of Heating, Refrigerating and Air-Conditioning Engineers, Inc. 2010.

73. Manfaluthy M, Wilyanti S, editors. LED efficacy as key indicator to evaluate bulb lighting. AIP Conference Proceedings; 2019: AIP Publishing LLC.

74. Ball M. RICS European housing review 2003: Royal Institution of Chartered Surveyors United Kingdom; 2003.

75. Joyce J. 2011 [Available from: www.bbc.co.uk/news/uk-14916580. 
77. Humphreys M, Nicol F, David J, Guy A, Handley D, Wood D. CIBSE Guide A: Environmental

687 Design. Norwich, UK: CIBSE Publications; 2006.

78. George A, Anto R, editors. Analytical and experimental analysis of optimal tilt angle of solar photovoltaic systems. 2012 International Conference on Green Technologies (ICGT); 2012: IEEE.

79. Ahmadian E, Sodagar B, Mills G, Bingham C, editors. Correlation of urban built form, density and energy performance. Journal of Physics: Conference Series; 2019: IOP Publishing.

80. Monien D, Strzalka A, Koukofikis A, Coors V, Eicker U. Comparison of building modelling assumptions and methods for urban scale heat demand forecasting. Future Cities and Environment. 2017;3(1):1-13.

695 81. Rafiee A, Dias E, Koomen E. Analysing the impact of spatial context on the heat consumption of individual households. Renewable and Sustainable Energy Reviews. 2019;112:461-70.

82. Hamilton I, Evans S, Steadman P, Godoy-Shimizu D, Donn M, Shayesteh H, et al. All the way to the top! The energy implications of building tall cities. CISBAT 2017; Switzerland2017. p. 493-8.

83. Lee JM, Braham W. Right-sizing cities for maximum power: urban form parameters for New York City and the Greater Philadelphia region. Sustainability. 2019;11(8):2352.

84. Salvati A, Palme M, Chiesa G, Kolokotroni M. Built form, urban climate and building energy modelling: case-studies in Rome and Antofagasta. Journal of Building Performance Simulation. 2020;13(2):209-25.

85. Evans S, Liddiard R, Steadman P. 3DStock: A new kind of three-dimensional model of the building stock of England and Wales, for use in energy analysis. Environment and Planning B: Urban Analytics and City Science. 2017;44(2):227-55.

86. Sarralde JJ, Quinn DJ, Wiesmann D, Steemers K. Solar energy and urban morphology: Scenarios for increasing the renewable energy potential of neighbourhoods in London. Renewable Energy. 2015;73:10-7.

87. Byrd H. The Power of Subarbia. In: Berger A, Kotkin J, Guzman CB, editors. Infinite Suburbia. New York: Princeton Architectural Pres; 2017. p. 608-23.

88. Ahmadian E, Byrd H, Sodagar B, Matthewman S, Kenney C, Mills G. Energy and the form of cities: the counterintuitive impact of disruptive technologies. Architectural Science Review. 2019;62(2):145-51.

\section{Nomenclature}

$717 \theta \quad$ Cut-off angle

$718 \quad \mathrm{ACH} \quad$ Air change per hour

719 BESTEST Building Energy Simulation Test

720 CIM Canopy Interface Model

721 Eequity Energy Equity indicator

722 g-value Solar energy transmittance

$723 \mathrm{~L} \quad$ Distance between buildings

724 LED Light-Emitting Diode

$725 \mathrm{n} \quad$ Number of storeys

726 PV Photovoltaic

727 SAP Standard Assessment Procedure

728 U-value Thermal transmittance

$729 \times \quad$ Plan depth 